\title{
Effects of stocking density on behavior, productivity, and comfort indices of lactating dairy cows
}

\author{
F. X. Wang, ${ }^{*}$ D. F. Shao, ${ }^{*}$ S. L. Li, ${ }^{*}$ Y. J. Wang, ${ }^{*}$ A. Azarfar, $†$ and Z. J. Cao*1 \\ *State Key Laboratory of Animal Nutrition, College of Animal Science and Technology, China Agricultural University, Beijing 100193, China \\ †Department of Animal Science, Faculty of Agriculture, Lorestan University, PO Box 465, Khorramabad, Iran
}

\begin{abstract}
The objective of this study was to investigate the effects of different stocking densities of 82 (0.82 cows per freestall and feed bin), 100, and $129 \%$ on behavior, productivity, and comfort indices of lactating Holstein dairy cows. Twenty-seven lactating cows (15 primiparous and 12 multiparous) were assigned to 1 of the 3 treatments, which were balanced for parity, milk yield, days in milk, and body weight in a $3 \times 3$ Latin square design with 14-d periods. After $7 \mathrm{~d}$ of adaptation to the treatments, lying time and bouts were recorded at 1-min intervals for $3 \mathrm{~d}$, DMI and feeding time were monitored electronically by feed bins, and rumination time was quantified at 2-h periods for $5 \mathrm{~d}$ during each period. The cow comfort index, stall standing index, stall perching index, and stall use index (SUI) were calculated using 10-min scan samples of video recording from d 8 to 10 of each period. Milk yield was recorded from d 8 to 12 and milk composition was determined from composite samples on d 12 in each period. Daily lying time, lying bouts, and bout duration did not differ among the stocking densities. The ratio of lying time $\geq 12 \mathrm{~h} / \mathrm{d}$ (the number of cows with daily lying time $\geq 12$ $\mathrm{h} / \mathrm{d}$ divided by number of cows per pen) was higher for cows housed at $82 \%$ stocking density compared with those housed at 100\% stocking density, with stocking density of $129 \%$ intermediate. Hourly lying time was lower at $100 \%$ stocking density compared with 82 and $129 \%$ stocking densities during the peak period (2300-0400 h), determined based on diurnal pattern of lying time. Daily dry matter intake, feeding time, and feeding rate were not affected by stocking density. After morning milking, dry matter intake and feeding time was reduced at 129 versus $82 \%$ stocking density during peak feeding time $(0600-0800 \mathrm{~h})$, determined based on diurnal patterns of feeding behavior. Stocking
\end{abstract}

Received July 10, 2015.

Accepted January 31, 2016.

${ }^{1}$ Corresponding author: caozhijun@cau.edu.cn. density had no effect on rumination time, milk yield and milk composition. The ratio of SUI $\geq 85 \%$ (mean of the number of SUI $\geq 85 \%$ divided by the number of SUI at 10-min scan samples during a 24-h period) was lower at 129 versus $82 \%$ stocking density, with stocking density of $100 \%$ intermediate. During peak lying time after evening milking (2300-0400 h), both cow comfort index and SUI were higher at 129 than at $100 \%$ stocking density. The SUI was lower $2 \mathrm{~h}$ after morning milking (0800-0900 h) for cows housed at 129\% compared with those housed at 82 and $100 \%$ stocking densities. In conclusion, when compared with 100\% stocking density, understocking contributed to natural behaviors of cows that including lying, feeding, and rumination behavior, whereas overstocking did not cause negative effect on behavior, productivity, and comfort indices of cows in this study.

Key words: dairy cow, stocking density, behavior, productivity, cow comfort

\section{INTRODUCTION}

Dairy cow welfare has become a hot topic in recent years, especially considering the rise of large-scale dairy farms. The most important concerns regarding dairy cow welfare include whether the dairy cow is feeling well, functioning well, and performing natural behavior (von Keyserlingk et al., 2009). Behavior and welfare of dairy cows is affected by the physical environment they are housed in (stall design, flooring type, feed bunk design, environmental quality, and so on) and by grouping strategy and stocking density (Krawczel and Grant, 2009). A practice employed by dairy farmers is to increase the herd size without extending housing facilities, which has resulted great farm to farm variation in stocking densities for stalls (number of cows per number of stalls $\times 100)$ and feed bunks $(61 \mathrm{~cm} /$ number of feed bunk spaces $\times 100)$ ranging between 71 to $197 \%$ and $58 \%$ to $228 \%$, respectively, on North American dairy farms (von Keyserlingk et al., 2012), and stall stocking density ranging from 59 to $161 \%$ on commercial freestall farms in China (Chapinal et al., 2014). 
The effect of stocking density on stall comfort, welfare, and natural behavior of cows can be evaluated by determining their resting, feeding, and rumination patterns (Krawczel and Grant, 2009) and using practical indices including cow comfort index (CCI; number of cows lying in stalls per number of cows in contact with stalls; Nelson, 1996), stall standing index (SSI; number of cows standing in stalls per number of cows in contact with stalls; Cook et al., 2005), stall perching index (number of cows standing with 2 front feet in the stall and the rear feet in the alley per number of cows in contact with stalls; Tucker et al., 2005), and stall use index (SUI; number of cows lying in stalls per number of cows not actively feeding; Overton et al., 2002). Krawczel et al. (2008) found that SUI reduced as stocking density increased from 100 to $142 \%$ with no change in CCI or SSI during 24-h periods. Recent studies indicate that overstocking of stalls and headlocks to about $115 \%$ did not affect daily lying and rumination time (Hill et al., 2009; Krawczel et al., 2012a), whereas increasing stocking density above $\sim 130 \%$ frequently resulted in reduced daily lying time (Fregonesi et al., 2007; Krawczel et al., 2012a), decreased eating time (Proudfoot et al., 2009; Krawczel et al., 2012b), and decreased the ratio of time spend ruminating within a stall (Krawczel et al., 2012a).

Previous findings indicated a positive correlation between milk production and lying time (Grant, 2007) as well as milk production and availability of lying stalls (Bach et al., 2008). Precursors for milk synthesis are provided by blood flowing to the mammary gland (Delamaire and Guinard-Flament, 2006), which is enhanced during lying (Rulquin and Caudal, 1992). Therefore, stocking density may affect milk production of dairy cows, as it has an effect on lying behavior of dairy cows (Krawczel et al., 2012a).

To our knowledge the effects of stocking densities representative of on-farm situations on diurnal patterns of behavior and cow comfort indices have not been studied before. Therefore, the aim of the current study was to investigate effects of different stocking densities [82, 100, and $129 \%$ (i.e., $0.82,1.00$, and 1.29 cows per stall and feed bin, respectively)] on daily and diurnal patterns of behavior, productivity, and comfort indices in lactating dairy cows.

\section{MATERIALS AND METHODS}

\section{Animals, Treatments, and Management}

Twenty-seven Holstein cows, including 15 primiparous and 12 multiparous, were selected and assigned to 1 of 3 pens balanced for parity $(1.80 \pm 0.06$; mean $\pm \mathrm{SD})$, milk yield $(35.03 \pm 5.19 \mathrm{~kg} / \mathrm{d})$, DIM $(192.07 \pm$ $23.15 \mathrm{~d})$, and BW $(493.47 \pm 50.31 \mathrm{~kg})$ at the beginning of the study. Three treatment stocking densities of 82 (11 stalls and feed bins for 9 cows), 100 (9 stalls and feed bins for 9 cows), and 129\% (7 stalls and feed bins for 9 cows) were applied to the 3 pens, with cows in a balanced $3 \times 3$ Latin square design with 14 -d periods that included $7 \mathrm{~d}$ of treatment acclimatization and $7 \mathrm{~d}$ of data collection. Each pen (20 m long, $12.75 \mathrm{~m}$ wide) contained 16 head-to-head waterbeds $(2.40 \mathrm{~m}$ long, $1.20 \mathrm{~m}$ wide; Advanced Comfort Technology Inc., Sun Prairie, WI) covered with 2.5 to $4.0 \mathrm{~cm}$ of rice husk, 16 electronic feed bins (1.00 wide, $0.75 \mathrm{~m}$ high, $0.84 \mathrm{~m}$ depth; Roughage Intake Control system, Insentec B.V, Marknesse, the Netherlands; validated by Chapinal et al., 2007), and one box-type water bin. Feed alleys and back alleys were 4.25 and $3.70 \mathrm{~m}$ wide, respectively, and scraped with an automatic scraper system (GEA Farm Technologies, Düsseldorf, Germany). The TMR fed to all cows was formulated according to recommendations in NRC (2001; Table 1) and was refilled twice daily at 0730 and $1430 \mathrm{~h}$ for ad libitum intake. Feed samples that were collected on d 8,11, and 14 of each experimental period for particle size distribution determination using a Penn State Particle Separator (Nasco, Fort Atkinson, WI); fresh feed samples were collected from d 8 to d 12 of each experimental period for DM and chemical composition analysis by State Key Laboratory of Animal Nutrition of China Agricultural University. Cows were milked 3 times daily at 0600, 1300, and 2000 $\mathrm{h}$ in a double-48 parallel parlor.

\section{Data Collection}

Environmental Conditions. The data of daily temperature and relative humidity were recorded at 5 -min intervals during the whole experimental period using a temperature data logger (HOBO Pendant G, Onset Computer Corp., Bourne, MA).

Lying Behavior. Data loggers (HOBO Pendant G, Onset Computer Corp.; validated by Ledgerwood et al., 2010) were attached to right hind leg along the metatarsus bone of all cows to record lying time and bouts at 1-min intervals from d 8 to 10 of each experimental period. To avoid any interference with lying behavior of cows, data loggers were attached on the night before starting data collection. Lying time was summarized in 1-h periods to draw the diurnal pattern of lying that was based on to determine peak periods of lying behavior. The recommended lying time for dairy cows by Dairy Farmers of Canada (2009) is 12 to 13 h/d (Fregonesi and Leaver, 2002; Fregonesi et al., 2007; Tucker et al., 2009). Therefore, the ratio of lying time 
$\geq 12 \mathrm{~h} / \mathrm{d}$ was calculated as the number of cows with daily lying time $\geq 12 \mathrm{~h} / \mathrm{d}$ divided by number of cows in each pen. Bout duration was calculated as total daily lying time divided by number of lying bouts per day.

Feeding Behavior. Individual feed intake and eating time were monitored by Insentec feed bins (Roughage Intake Control system, Insentec B.V; validated by Chapinal et al., 2007). Data were summed to calculate total DMI and feeding time per 24- and 2-h periods for $5 \mathrm{~d}$. Diurnal patterns of feeding behavior that reflected the peak periods of feeding were drawn according to the data of DMI and feeding time per 2-h periods. Feeding rate was calculated as total daily DMI divided by total daily feeding time.

Rumination Behavior. Rumination time was quantified using HR-Tags (SCR Engineers Ltd., Netanya, Israel; validated by Schirmann et al., 2009) that were fitted to the left side of the neck of each cow from d 8 to 12 of each experimental period and averaged in 2-h periods.

Milk Samples. During each experimental period, milk yield of each cow was recorded at each milking from d 8 to 12 . On d 12 of each experimental period, milk samples were collected during all 3 milkings for milk composition analysis including fat, protein, lactose, and SCC (Dairy Products Quality Supervision and Inspection Center, Beijing, China). Fat-corrected milk (3.5\% FCM) was calculated using the equation $[0.432 \times$ milk yield $(\mathrm{kg} / \mathrm{d})+16.23 \times$ milk fat yield $(\mathrm{kg} / \mathrm{d})](\mathrm{NRC}$, 2001); and ECM was calculated as $[0.327 \times$ milk yield $(\mathrm{kg} / \mathrm{d})+12.95 \times$ milk fat yield $(\mathrm{kg} / \mathrm{d})+7.2 \times$ milk protein yield (kg/d)] (Tyrrell and Reid, 1965).

Comfort Indices. The number of cows lying in a stall, standing in a stall, perching in a stall, standing in the alley but not eating, and eating at feed bunks were counted by 10 -min scan samples of video recording for $24 \mathrm{~h}$ starting from d 8 to 10 of each experimental period. The video data were collected using a digital video software (DS-7808, Hikvision, Zhejiang, China) with 6 cameras (AJ-86A, Aijia, Zheijiang, China) mounted to the periphery of the pen at $4.60 \mathrm{~m}$ over the floor. Data were analyzed to calculate CCI (Nelson, 1996), SSI (Cook et al., 2005), stall perching index (Tucker et al., 2005), and SUI (Overton et al., 2002).

\section{Statistical Analyses}

Behavior (lying, feeding, and rumination) and comfort indices collected at 24-h periods or peak periods (based on the diurnal patterns of behavior identified visually by plotting the data in graphs), and productivity data were analyzed as a $3 \times 3$ Latin square design with period and treatment (stocking density) as fixed effects and pen (experimental unit) as a random effect using the MIXED procedure of SPSS 22.0 (IBM Corp. Armonk, NY). All data were tested for normality and homogeneity of variances using SPSS 22.0. Extreme outliers (the difference value between figure and average value is 3 times higher than the standard deviation) were detected and removed using the descriptive statistics procedure of SPSS 22.0. Data of diurnal patterns of behavior and cow comfort indices were analyzed considering hourly periods (averaged in 2-h bins, expressed as 1-h values) as repeated measures using a repeated measures mixed model (MIXED procedure of SPSS 22.0), including fixed effects for period and treatment (stocking density) and a random effect of pen (experimental unit). The lowest Bayesian information criterion (fit statistic) level was used to select covariance structure of the model for each parameter. The least significant difference test was used for multiple treatment comparisons. Significance was declared at $P$ $\leq 0.05$.

Table 1. Ingredient and chemical composition (\% of DM) of the TMR

\begin{tabular}{lc}
\hline Item & Measurement \\
\hline Diet ingredient (\% of DM) & \\
Corn silage & 21.3 \\
Alfalfa hay & 11.3 \\
Oat grass hay & 0.5 \\
Flaked corn & 15.5 \\
Corn & 8.0 \\
Extruded soybean & 1.3 \\
Soybean meal & 10.0 \\
Whole cottonseed & 8.0 \\
DDGS & 8.7 \\
Beet pulp & 3.8 \\
Apple pomace & 1.9 \\
Canola & 1.4 \\
Molasses & 1.8 \\
Rumen bypass fat & 1.6 \\
Yeast culture & 0.7 \\
Zeolite & 0.1 \\
Salt & 0.4 \\
Calcium carbonate & 1.2 \\
Sodium bicarbonate & 1.4 \\
Potassium bicarbonate & 0.7 \\
Premix & 0.6 \\
Magnesium oxide & 0.2 \\
Chemical composition (\% of DM, unless noted) & \\
DM (\% of fresh) & 58.6 \\
CP & 17.4 \\
Ether extract & 4.2 \\
NDF & 32.8 \\
ADF & 17.9 \\
Ash & 11.3 \\
NFC & 88.9 \\
Ca & 34.2 \\
P NE (Mcal/kg) & 0.8 \\
NE & 0.4 \\
\hline & 1.71 \\
\hline DDS - &
\end{tabular}

${ }^{1}$ DDGS $=$ dried distillers grains with solubles.

${ }^{2} \mathrm{OM}(\%)=100-\operatorname{ash}(\%)$.

${ }^{3} \mathrm{NFC}(\%)=100-\mathrm{CP}(\%)-$ ether extract $(\%)-\mathrm{NDF}(\%)-\operatorname{ash}(\%)$. 


\section{RESULTS}

\section{Environmental Conditions and Particle Size Distribution of TMR}

During the trial, mean daily temperature and relative humidity were $23.1^{\circ} \mathrm{C}$ and $73.7 \%$, ranging from 11.0 to $33.0^{\circ} \mathrm{C}$ and 22.9 to $97.7 \%$, respectively. The long, medium, short, and fine particle size of TMR using Penn State Particle Separator (mean $\pm \mathrm{SD}$ ) were $4.2 \pm 0.7$, $41.4 \pm 1.2,37.9 \pm 1.7$, and $14.0 \pm 0.8 \%$, respectively.

\section{Lying Behavior}

Daily lying time $(11.91 \pm 0.39 \mathrm{~h} / \mathrm{d})$, lying bouts $(13.13 \pm 0.72 \mathrm{n} / \mathrm{d})$, and bout duration $(59.87 \pm 3.27$ $\mathrm{min} /$ bout) did not differ among the stocking densities (Table 2). The ratio of lying time $\geq 12 \mathrm{~h} / \mathrm{d}$ was higher in $82 \%$ stocking density compared with $100 \%$ stocking density, with a stocking density of $129 \%$ being intermediate $(P=0.04$; Table 2$)$. The diurnal pattern of lying time indicated 4 distinct peak periods of lying activity: one from 2300 to $0400 \mathrm{~h}$ and other peak periods of lying activities beginning $2 \mathrm{~h}$ after each milking (0800-0900, 1500-1600, and 2200-2300 h; Figure 1). Hourly lying time was lower at $100 \%$ stocking density compared with 82 and $129 \%$ stocking densities during 2300 to 0400 h $(P=0.02$; Table 2$)$.

\section{Feeding Behavior}

Daily DMI $(23.02 \pm 0.57 \mathrm{~kg} / \mathrm{d})$, feeding time $(2.56 \pm$ $0.13 \mathrm{~h} / \mathrm{d})$, and feeding rate $(158.32 \pm 8.96 \mathrm{~g} / \mathrm{min})$ were not affected by stocking density (Table 3 ). Cows spent more time on feeding activity during the day (0600-1800 $\mathrm{h}$ ), with feeding rate per hour being numerically lower

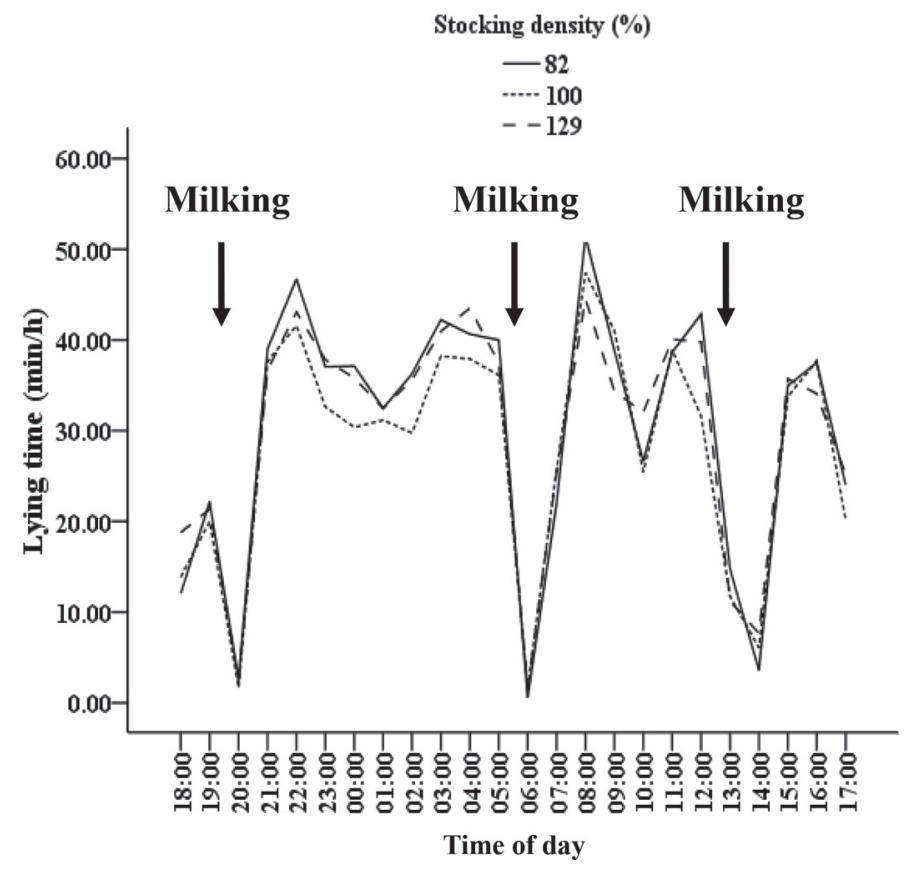

Figure 1. Diurnal pattern of mean lying time per hour of dairy cows $(\mathrm{n}=9$ cows $/$ pen $)$ within a 24 -h period at stocking densities $(\mathrm{n}=$ 3 pens/treatment) of $82(-), 100(\cdots)$, and $129 \%$ (- - i.e., 0.82, 1.00, and 1.29 cows per stall and feed bin, respectively). Cows were fed approximately at 0730 and $1430 \mathrm{~h}$, and milked at 0600, 1300, and 2000 $\mathrm{h}$ (black arrows).

during the day (0600-1800 h) for cows housed at $82 \%$ stocking density compared with 100 or $129 \%$ stocking density (Figure 2C). Feeding activity reached its peak within $1 \mathrm{~h}$ after returning to their pens from milking (0600-0800, 1400-1600, and 2000-2200 h; Figures 2A), and cows housed at $82 \%$ stocking density had a higher DMI $(P=0.04)$ and a longer feeding time $(P=0.03)$ after morning feed delivery (0600-0800 h; Table 3).

Table 2. Mean lying behavior of dairy cows at different stocking densities over $3 \mathrm{~d}$ for 9 cows per pen $(\mathrm{n}=3$ pens/treatment)

\begin{tabular}{|c|c|c|c|c|c|}
\hline \multirow[b]{2}{*}{ Variable } & \multicolumn{3}{|c|}{ Stocking density ${ }^{1}(\%)$} & \multirow[b]{2}{*}{ SEM } & \multirow[b]{2}{*}{$P$-value } \\
\hline & 82 & 100 & 129 & & \\
\hline Lying time $(\mathrm{h} / \mathrm{d})$ & 12.19 & 11.79 & 11.75 & 0.39 & 0.63 \\
\hline Lying bouts (n/d) & 14.14 & 12.23 & 13.01 & 0.72 & 0.19 \\
\hline Bout duration (min/bout) & 56.65 & 62.97 & 60.00 & 3.27 & 0.42 \\
\hline Ratio of lying time $\geq 12 \mathrm{~h} / \mathrm{d}^{2}(\%)$ & $63.43^{\mathrm{a}}$ & $37.85^{\mathrm{b}}$ & $49.15^{\mathrm{ab}}$ & 4.67 & 0.04 \\
\hline \multicolumn{6}{|l|}{ Peak lying time ${ }^{3}(\min / h)$} \\
\hline $2300-0400 \mathrm{~h}$ & $37.90^{\mathrm{a}}$ & $34.06^{\mathrm{b}}$ & $38.11^{\mathrm{a}}$ & 1.17 & 0.02 \\
\hline 0800-0900 h & 51.42 & 47.40 & 44.54 & 2.37 & 0.13 \\
\hline $1500-1600 \mathrm{~h}$ & 34.97 & 33.75 & 35.72 & 2.90 & 0.92 \\
\hline $2200-2300 \mathrm{~h}$ & 46.73 & 41.59 & 43.09 & 2.35 & 0.32 \\
\hline
\end{tabular}




\section{Rumination Behavior}

Stocking density had no effect on daily rumination time $(6.15 \pm 0.30 \mathrm{~h} / \mathrm{d}$; Table 3$)$. Compared with the 100 and $129 \%$ stocking densities, cows housed at $82 \%$ stocking density exhibited 2 more distinct rumination peaks which occurred at 0800 to $1000 \mathrm{~h}$ and 1200 to 1400 h (Figure 3).

\section{Productivity}

Milk yield and composition were not affected by the stocking density $(P>0.05$; Table 4$)$.

\section{Comfort Indices}

The ratio of SUI $\geq 85 \%$ was reduced at 129 versus $82 \%$ stocking density, with $100 \%$ stocking density being intermediate $(P=0.048$; Figure 4$)$. During peak lying time, at 2300 to $0400 \mathrm{~h}$, both CCI and SUI were higher at 129 than at $100 \%$ stocking density $(P<0.001$; Table $5)$. During peak lying time after morning milking (0800-0900 h), SUI was lower for cows housed at $129 \%$ compared with those housed at 82 and 100\% stocking densities $(P<0.001$; Table 5$)$.

\section{DISCUSSION}

The aim of the current study was to determine the effects of 3 stocking densities (82, 100, and 129\%) on natural behavior of lactating dairy cows in terms of daily and diurnal patterns of lying, feeding and ruminating, productivity, and comfort indices. Our main findings were that varying stocking densities had no effect on daily behaviors, including time spent lying, feeding, and ruminating or on milk production and composition in this trial. However, lying time during peak periods (2300-0400 h) and feeding time during peak periods (0600-0800 h) were higher when cows were housed at $82 \%$ stocking density and coincided with increased SUI (especially compared with $100 \%$ stocking density), and CCI and SUI were enhanced at 129\% stocking density during the peak lying period (2300-0400 h).

\section{Lying Behavior}

Daily lying time was not affected by decreasing the stocking density from 100 to $82 \%$, which was similar to finding of Telezhenko et al. (2012). Wagner-Storch et al. (2003) found the maximum stall occupancy to range from 62 to $88 \%$ when stocking density was $100 \%$, which might explain that reducing stocking density from 100 to $82 \%$ did not increase lying time in our study. Overstocking to $129 \%$ in the current trial had little effect on daily lying time, which was different from a recent study where daily lying time declined when stocking density increased beyond $113 \%$ (Krawczel et al., 2012a). The main difference between this trial and that of Krawczel et al. (2012a) was the group size (9

Table 3. Mean feeding behavior and rumination time of dairy cows at different times and stocking densities over $5 \mathrm{~d}$ for 9 cows per pen ( $\mathrm{n}=3$ pens/treatment)

\begin{tabular}{|c|c|c|c|c|c|}
\hline \multirow[b]{2}{*}{ Variable } & \multicolumn{3}{|c|}{ Stocking density $^{1}(\%)$} & \multirow[b]{2}{*}{ SEM } & \multirow[b]{2}{*}{$P$-value } \\
\hline & 82 & 100 & 129 & & \\
\hline DMI (kg/d) & 22.99 & 22.87 & 23.21 & 0.57 & 0.91 \\
\hline Feeding time $(\mathrm{h} / \mathrm{d})$ & 2.70 & 2.43 & 2.54 & 0.13 & 0.36 \\
\hline 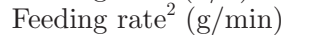 & 154.24 & 158.38 & 162.33 & 8.96 & 0.82 \\
\hline Rumination time $(\mathrm{h} / \mathrm{d})$ & 6.12 & 6.19 & 6.14 & 0.30 & 0.99 \\
\hline \multirow{2}{*}{\multicolumn{6}{|c|}{ Peak feeding behavior ${ }^{3}$}} \\
\hline & & & & & \\
\hline DMI (kg) & $3.33^{\mathrm{a}}$ & $2.72^{\mathrm{ab}}$ & $2.59^{\mathrm{b}}$ & 0.23 & 0.04 \\
\hline Feeding time (min) & $22.44^{\mathrm{a}}$ & $16.50^{\mathrm{b}}$ & $16.95^{\mathrm{b}}$ & 1.87 & 0.03 \\
\hline Feeding $\operatorname{rate}^{2}(\mathrm{~g} / \mathrm{min})$ & 161.22 & 178.15 & 171.10 & 10.09 & 0.50 \\
\hline \multicolumn{6}{|l|}{$1400-1600 \mathrm{~h}$} \\
\hline DMI (kg) & 3.56 & 3.27 & 3.57 & 0.21 & 0.53 \\
\hline Feeding time $(\min )$ & 21.25 & 19.04 & 20.62 & 1.74 & 0.66 \\
\hline Feeding $\operatorname{rate}^{2}(\mathrm{~g} / \mathrm{min})$ & 181.85 & 190.34 & 202.31 & 12.99 & 0.53 \\
\hline \multicolumn{6}{|l|}{$2000-2200 \mathrm{~h}$} \\
\hline DMI (kg) & 1.87 & 2.11 & 2.06 & 0.21 & 0.69 \\
\hline Feeding time $(\min )$ & 12.72 & 12.80 & 13.07 & 1.40 & 0.98 \\
\hline Feeding rate $^{2}(\mathrm{~g} / \mathrm{min})$ & 160.51 & 173.28 & 170.93 & 12.80 & 0.76 \\
\hline
\end{tabular}

a,b Means within a row with different superscripts differ $(P<0.05)$.

${ }^{1}$ Stocking densities were $0.82,1.00$, and 1.29 cows per stall and feed bin.

${ }^{2}$ Feeding rate equals the mean of DMI divided by feeding time.

${ }^{3}$ Peak feeding behavior times were identified based on visual observation based on plotting hourly data in graphs. 


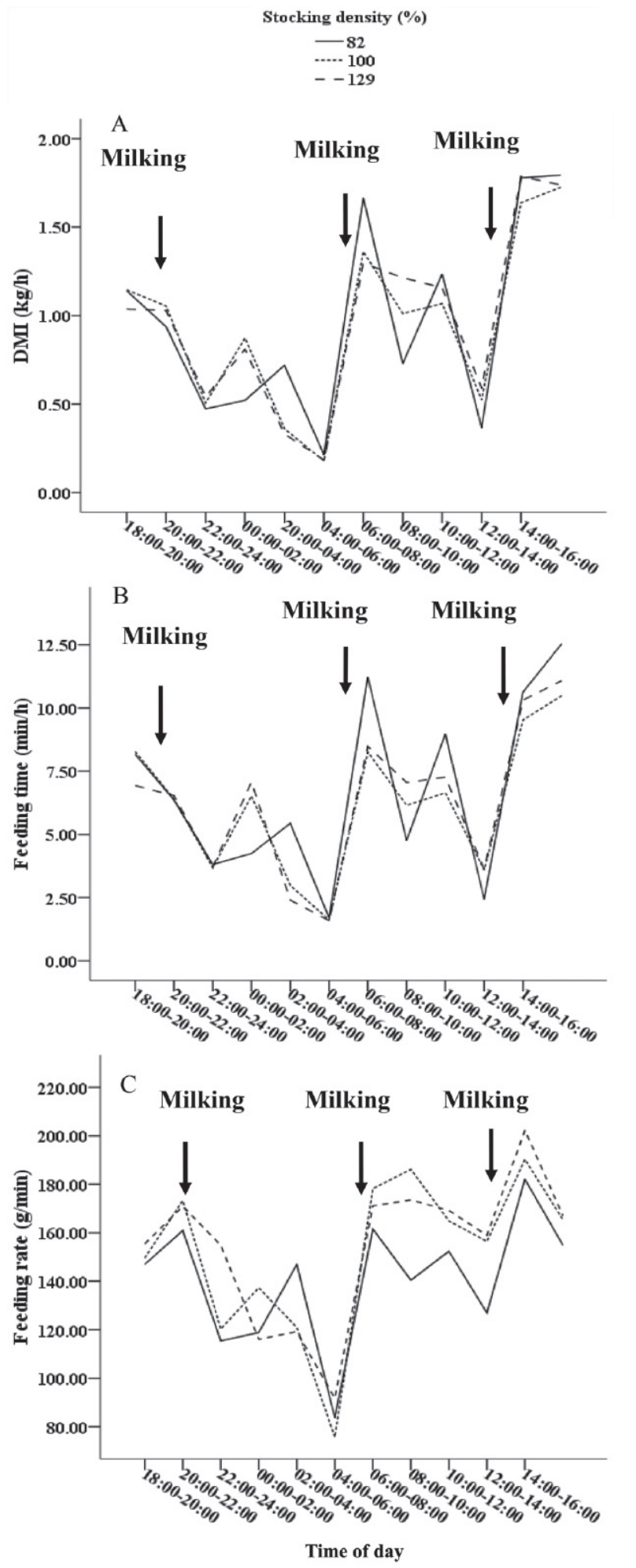

Figure 2. Diurnal patterns of mean DMI per hour (A), mean minutes of feeding per hour (B), and mean feeding rate (C) in 2-h periods of dairy cows $(\mathrm{n}=9$ cows/pen) within a 24 -h period at stocking densities $(\mathrm{n}=3 \mathrm{pens} /$ treatment) of $82(-), 100(\cdots)$, and $129 \%$ (- -; i.e., $0.82,1.00$, and 1.29 cows per stall and feed bin, respectively). Cows were fed approximately at 0730 and $1430 \mathrm{~h}$, and milked at 0600, 1300, and $2000 \mathrm{~h}$ (black arrows).

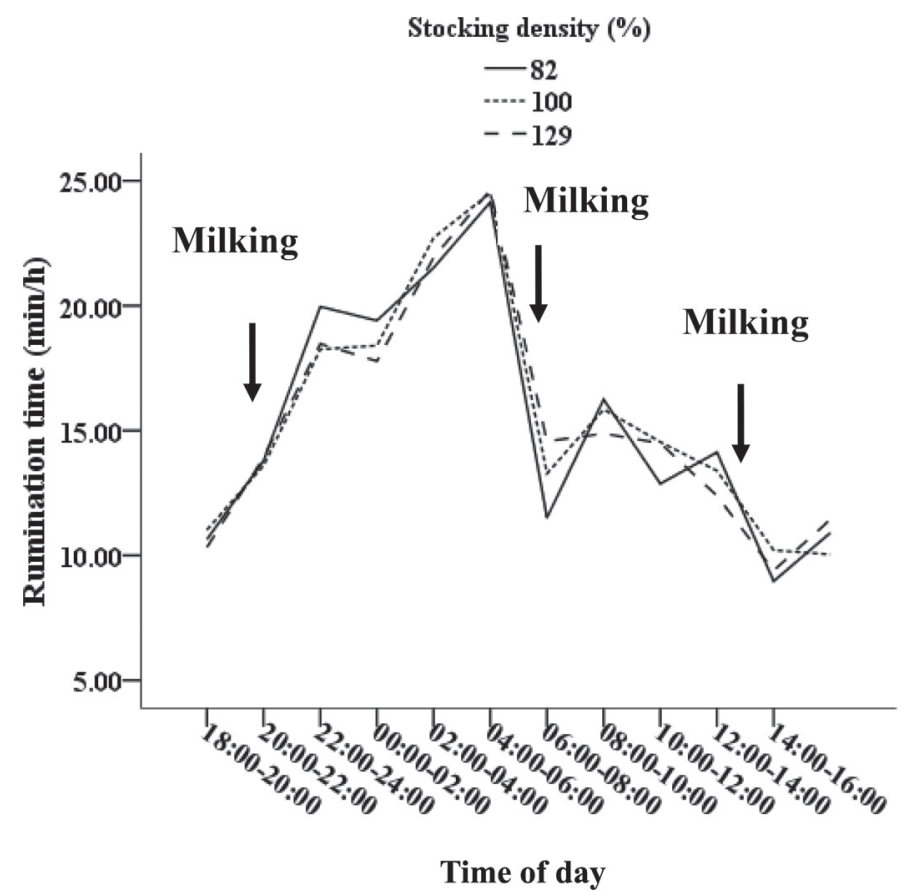

Figure 3. Diurnal patterns of mean rumination time per hour in 2-h periods of the dairy cows $(\mathrm{n}=9$ cows/pen) within a 24-h period at stocking densities $(\mathrm{n}=3$ pens/treatment) of $82(-), 100(\cdots)$, and $129 \%$ (- -; i.e., $0.82,1.00$, and 1.29 cows per stall and feed bin, respectively). Cows were fed approximately at 0730 and $1430 \mathrm{~h}$, and milked at 0600,1300 , and $2000 \mathrm{~h}$ (black arrows).

vs. 34 cows, respectively), which might have affected the response in daily lying times to overstocking differently, because overcrowding may not only occur at stalls with increasing group size but may also occur at the feed bunks and walkways. Therefore, cows housed in a larger group may experience more reduced laying time in response to overstocking than cows in smaller groups (Krawczel and Grant, 2009).

The recommended lying time for dairy cows by Dairy Farmers of Canada (2009) is 12 to $13 \mathrm{~h} / \mathrm{d}$ (Fregonesi and Leaver, 2002; Fregonesi et al., 2007; Tucker et al., 2009), which was, on average, achieved for all stocking densities. However, the proportion of cows having lying time greater than $12 \mathrm{~h} / \mathrm{d}$ was higher for cows housed at $82 \%$ than those housed at 100 and $129 \%$ stocking density. This suggests that increased stocking density may mainly decrease lying time of specific dairy cows within a pen, especially subordinate cows (Galindo and Broom, 2000).

Our study and others (DeVries and von Keyserlingk, 2005; Fregonesi et al., 2007; Schirmann et al., 2012) found the peak lying periods were at midnight and $2 \mathrm{~h}$ after milking. During the peak lying time (2300-0400 h), cows housed at $129 \%$ stocking density had longer lying time $(\mathrm{min} / \mathrm{h})$ relative to those housed at $100 \%$ 
Table 4. Effect of stocking densities on mean milk yield and composition for 9 cows on each pen ( $\mathrm{n}=3$ pens/ treatment)

\begin{tabular}{|c|c|c|c|c|c|}
\hline \multirow[b]{2}{*}{ Variable } & \multicolumn{3}{|c|}{ Stocking density ${ }^{1}(\%)$} & \multirow[b]{2}{*}{ SEM } & \multirow[b]{2}{*}{$P$-value } \\
\hline & 82 & 100 & 129 & & \\
\hline Milk yield (kg/d) & 33.09 & 31.91 & 33.11 & 1.14 & 0.71 \\
\hline $3.5 \%$ FCM $(\mathrm{kg} / \mathrm{d})$ & 35.12 & 34.39 & 35.38 & 1.39 & 0.87 \\
\hline $\operatorname{ECM}(\mathrm{kg} / \mathrm{d})$ & 35.14 & 34.37 & 35.49 & 1.30 & 0.83 \\
\hline \multicolumn{6}{|l|}{ Milk composition } \\
\hline Fat $(\%)$ & 3.84 & 3.94 & 3.96 & 0.16 & 0.86 \\
\hline Protein (\%) & 3.26 & 3.27 & 3.31 & 0.05 & 0.72 \\
\hline Lactose (\%) & 4.90 & 4.90 & 4.89 & 0.04 & 0.97 \\
\hline $\mathrm{SCC}(\times 1,000 / \mathrm{mL})$ & 87.25 & 87.67 & 98.42 & 20.47 & 0.91 \\
\hline
\end{tabular}

${ }^{1}$ Stocking densities were $0.82,1.00$, and 1.29 cows per stall and feed bin.

stocking density. Overstocking was previously found to result in rescheduling of daily time target, due to shortterm deprivation of lying, to recover the lost lying time (Metz, 1985; Cooper et al., 2007), and stall occupation time was found to increase as a result of fewer available stalls per cow (Fregonesi et al., 2007). However, deprivation from lying when stalls are not available might increase discomfort behaviors such as leg stomping, repositioning, and weight-shifting (Cooper et al., 2007); this needs further long-term exploration in overstocked housing.

\section{Feeding Behavior}

We observed that understocked cows had greater DMI and longer feeding time during the peak feeding period in the morning $(0600-0800 \mathrm{~h})$, with a lower value of feeding rate during the daytime (0600-1800 h) compared with cows at higher stocking rates. This

Table 5. Comparison of different stocking densities on cow comfort index (CCI) and stall use index (SUI) of dairy cows ( $\mathrm{n}=9$ cows $/$ pen) over $3 \mathrm{~d}$ at 10 -min scan samples during peak lying periods in each pen $(\mathrm{n}=3$ pens/treatment $)$

\begin{tabular}{lccccc}
\hline & \multicolumn{3}{c}{ Stocking density $^{1}(\%)$} & & \\
\cline { 2 - 4 } Variable & 82 & 100 & 129 & SEM & $P$-value \\
\hline 2300-0400 h & & & & & \\
CCI & $80.75^{\mathrm{b}}$ & $79.02^{\mathrm{b}}$ & $85.32^{\mathrm{a}}$ & 1.12 & $<0.001$ \\
SUI & $68.98^{\mathrm{a}}$ & $59.98^{\mathrm{c}}$ & $63.94^{\mathrm{b}}$ & 1.15 & $<0.001$ \\
0800-0900 h & & & & & \\
CCI & 93.47 & 95.44 & 95.51 & 1.73 & 0.64 \\
SUI & $91.75^{\mathrm{a}}$ & $92.38^{\mathrm{a}}$ & $75.65^{\mathrm{b}}$ & 1.93 & $<0.001$ \\
1500-1600 h & & & & & \\
CCI & 87.45 & 85.89 & 92.44 & 2.02 & 0.06 \\
SUI & 77.62 & 68.26 & 72.00 & 2.89 & 0.09 \\
2200-2300 h & & & & & \\
CCI & 87.04 & 83.14 & 85.42 & 1.90 & 0.34 \\
SUI & $81.31^{\mathrm{a}}$ & $71.18^{\mathrm{b}}$ & $65.38^{\mathrm{b}}$ & 2.61 & $<0.001$ \\
\hline
\end{tabular}

\footnotetext{
${ }^{\mathrm{a}-\mathrm{c}}$ Means within a row with different superscripts differ $(P<0.05)$.

${ }^{1}$ Stocking densities were $0.82,1.00$, and 1.29 cows per stall and feed bin.
}

indicates that overstocked cows would have to increase their feeding rate during quite feeding periods to meet their needs, as overstocking may increase competition around and availability of feed bunks (Collings et al., 2011), which might reduce the chewing time, saliva production, and ruminal $\mathrm{pH}$. We found that overstocking at the level of $129 \%$ had no effect on daily feeding time and DMI, similar to the findings of Krawczel et al. (2012a). However, others found that daily feeding time increased linearly as the feed bunk space increased $(0.21,0.41,0.61$, and $0.81 \mathrm{~m} / \mathrm{cow}$, corresponding to

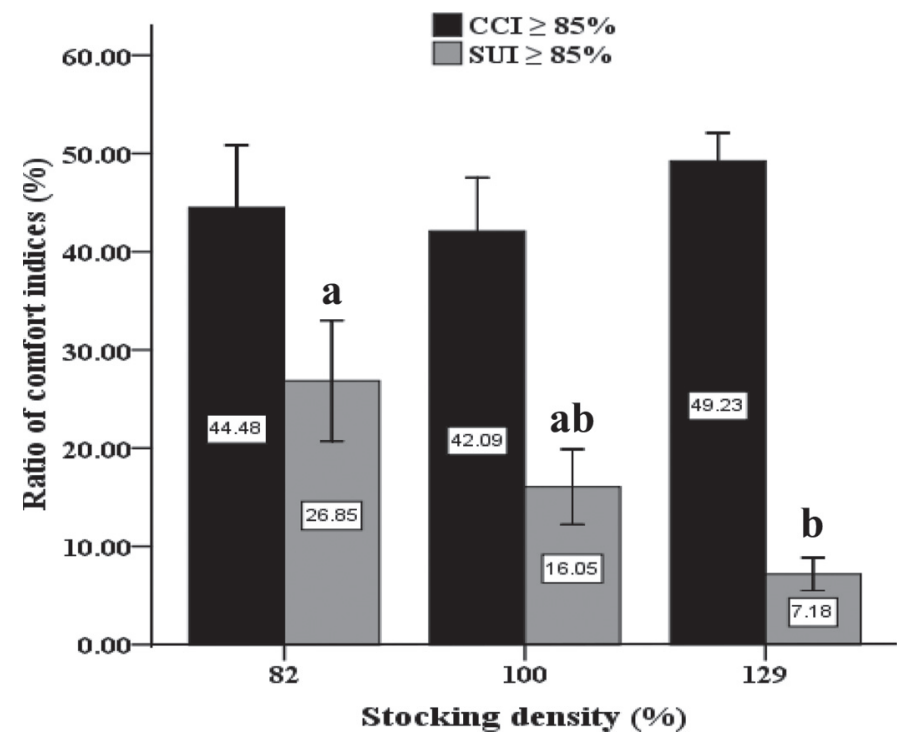

Figure 4. Ratio of cow comfort index (CCI) and stall use index (SUI) greater than or equal to $85 \%$ of dairy cows $(n=9$ cows $/$ pen $)$ at each stocking density $(82,100$, and 129\%) for 3 d using 10-min scan samples during a 24 -h period in each pen ( $\mathrm{n}=3$ pens/treatment). Ratio of CCI $\geq 85 \%$ (black bars; $P=0.63$; mean of the number of CCI $\geq 85 \%$ divided by the number of CCI at 10-min scan samples during a 24 -h period), ratio of SUI $\geq 85 \%$ (gray bars; $P=0.048$; mean of the number of SUI $\geq 85 \%$ divided by the number of SUI at 10 -min scan samples during a 24-h period), and bars with different superscripts (a, b) differ $(P<0.05)$. Error bars indicate $\pm 1 \mathrm{SE}$. 
303, 149, 100, and $75 \%$ stocking densities, respectively; Huzzey et al., 2006), and that daily feeding time increased when doubling feed alley space from 0.50 ( $122 \%$ stocking density) to $1.00 \mathrm{~m} / \mathrm{cow}$ (61\% stocking density; DeVries et al., 2004). The difference between our findings and those reported by others (Huzzey et al., 2006; DeVries et al., 2004) might be associated with the different types of feed troughs used, because feed bins with vertical head gates separating consecutive bins in a row, which were used in our trial, would reduce cow displacement at feed bins when they were exposed to overstocking. Daily feeding time was shorter in our study than those reported by others (Fregonesi and Leaver, 2002; Krawczel et al., 2012a,b). This might be attributed to a high proportion of concentrate and low proportion of long particles in the ration used in the current study, which were previously both found to decrease feeding time (Yang et al., 2001).

\section{Rumination Behavior}

No response was noted in daily rumination time among stacking densities in our study, consistent with previous findings in which the respective range of stocking densities varied from 67 to $142 \%$ (Fregonesi and Leaver, 2002; Krawczel et al., 2012a,b). Krawczel et al. (2012a) found that increasing stocking density from 100 to $142 \%$ decreased the ratio of time spend ruminating within a stall, and Schirmann et al. (2012) found a positive relationship between rumination time and lying time. In our study and others (Adin et al., 2009; Hart et al., 2013, 2014), cows spent more time ruminating at night, most likely because it corresponded to their highest lying time. During the day (0600-1800 $\mathrm{h}$ ), the pattern of rumination time per hour fluctuated more for cows housed at $82 \%$ stocking density compared with those housed at 100 and $129 \%$ stocking densities (Figure 3A), which may be related to differences in feeding behavior of dairy cows as affected by different stocking densities (see feeding behavior section).

\section{Productivity}

Milk yield was not influenced by stocking density in our study, which was consistent with previous findings for dairy cows housed at either 100 or 142\% (Krawczel et al., 2012a). Previous studies indicated a positive correlation between milk production and lying time (Grant, 2007), as well as between milk production and availability of stalls (Bach et al., 2008). Therefore, the absence of an effect of stocking density on daily lying and feeding time in our study might explain why milk yield was not affected by the stocking density.

\section{Comfort Indices}

In our study, CCI was highest at stocking density of $129 \%$ during the peak lying period $(230-0400 \mathrm{~h})$. This might be due to cows at higher stocking densities laying down sooner and occupying the stall for longer periods of time after the night milking (Fregonesi et al., 2007). Consequently, the number of standing cows within a stall decreases as stocking density increases over $113 \%$ (Hill et al., 2009). However, Krawczel et al. (2008) observed no change in CCI with increasing stocking density from 100 to $142 \%$ during peak lying time (0000-0400 h). This was likely because, in their study, alley surfaces within the pen were covered with rubber mats which tended to diminish the effect of high-stocking density standing and perching in a stall by cows. The ideal CCI was suggested to be above $85 \%$ (Overton et al., 2002; 2003). The ratio of CCI $\geq 85 \%$ and SUI $\geq 85 \%$ did not differ between 100 and $129 \%$ stocking densities, but cows kept at $129 \%$ stocking density had a lower ratio of SUI $\geq 85 \%$ compared with those kept at $82 \%$ stocking density; this was in agreement with findings of Krawczel et al. (2008).

\section{CONCLUSIONS}

Varying stocking densities of 82, 100, and 129\% per stall and per feed bin had no effect on daily time spent lying, feeding, and ruminating in this trial. Milk yield and composition of cows were not affected by stocking density. Compared with 100\% stocking density, the peak lying time (2300-0400 h) and peak feeding time (0600-0800 h) were increased at $82 \%$ stocking density, which coincided with increased SUI. The behavioral index did not differ between 100 and 129\% stocking densities, whereas CCI and SUI were enhanced at $129 \%$ stocking density during the peak lying period (2300-0400 h).

\section{ACKNOWLEDGMENTS}

The authors are grateful for the financial support of Beijing Nova Program (China; Z121105002512067), Beijing Young Scientist Program (China; YETP0305), China Agriculture Research System (Beijing, China; CARS-37), and Key Technologies R\&D Program of China (Beijing, China; 2012BAD12B02).

\section{REFERENCES}

Adin, G., R. Solomon, M. Nikbachat, A. Zenou, E. Yosef, A. Brosh, A. Shabtay, S. J. Mabjeesh, I. Halachmi, and J. Miron. 2009. Effect of feeding cows in early lactation with diets differing in roughageneutral detergent fiber content on intake behavior, rumination, and milk production. J. Dairy Sci. 92:3364-3373. 
Bach, A., N. Valls, A. Solans, and T. Torrent. 2008. Associations between nondietary factors and dairy herd performance. J. Dairy Sci. 91:3259-3267.

Chapinal, N., Y. Liang, D. M. Weary, Y. Wang, and M. A. G. Von Keyserlingk. 2014. Risk factors for lameness and hock injuries in Holstein herds in China. J. Dairy Sci. 97:4309-4316.

Chapinal, N., D. M. Veira, D. M. Weary, and M. A. G. Von Keyserlingk. 2007. Technical note: Validation of a system for monitoring individual feeding and drinking behavior and intake in grouphoused cattle. J. Dairy Sci. 90:5732-5736.

Collings, L. K. M., D. M. Weary, N. Chapinal, and M. A. G. von Keyserlingk. 2011. Temporal feed restriction and overstocking increase competition for feed by dairy cattle. J. Dairy Sci. 94:5480-5486.

Cook, N. B., T. B. Bennett, and K. V. Nordlund. 2005. Monitoring indices of cow comfort in free-stall-housed dairy herds. J. Dairy Sci. 88:3876-3885.

Cooper, M. D., D. R. Arney, and C. J. Phillips. 2007. Two- or fourhour lying deprivation on the behavior of lactating dairy cows. J. Dairy Sci. 90:1149-1158.

Dairy Farmers of Canada. 2009. Code of Practice for the Care and Handling of Dairy Cattle. Dairy Farmers of Canada, Ottawa, ON, Canada.

Delamaire, E., and J. Guinard-Flament. 2006. Increasing milking intervals decreases the mammary blood flow and mammary uptake of nutrients in dairy cows. J. Dairy Sci. 89:3439-3446.

DeVries, T. J., and M. A. von Keyserlingk. 2005. Time of feed delivery affects the feeding and lying patterns of dairy cows. J. Dairy Sci. $88: 625-631$

DeVries, T. J., M. A. von Keyserlingk, and D. M. Weary. 2004. Effect of feeding space on the inter-cow distance, aggression, and feeding behavior of free-stall housed lactating dairy cows. J. Dairy Sci. $87: 1432-1438$.

Fregonesi, J. A., and J. D. Leaver. 2002. Influence of space allowance and milk yield level on behaviour, performance and health of dairy cows housed in strawyard and cubicle systems. Livest. Prod. Sci. 78:245-257.

Fregonesi, J. A., C. B. Tucker, and D. M. Weary. 2007. Overstocking reduces lying time in dairy cows. J. Dairy Sci. 90:3349-3354.

Galindo, F., and D. M. Broom. 2000. The relationships between social behavior of dairy cows and the occurrence of lameness in three herds. Res. Vet. Sci. 69:75-79.

Grant, R. 2007. Taking advantage of natural behavior improves dairy cow performance. Pages 225-236 in Proc. Western Dairy Manag. Conf., Reno, NV. Kansas State University Press, Manhattan.

Hart, K. D., B. W. Mcbride, T. F. Duffield, and T. J. Devries. 2013 Effect of milking frequency on the behavior and productivity of lactating dairy cows. J. Dairy Sci. 96:6973-6985.

Hart, K. D., B. W. Mcbride, T. F. Duffield, and T. J. Devries. 2014. Effect of frequency of feed delivery on the behavior and productivity of lactating dairy cows. J. Dairy Sci. 97:1713-1724.

Hill, C. T., P. D. Krawczel, H. M. Dann, C. S. Ballard, R. C. Hovey, W. A. Falls, and R. J. Grant. 2009. Effect of stocking density on the short-term behavioural responses of dairy cows. Appl. Anim. Behav. Sci. 117:144-149.

Huzzey, J. M., T. J. Devries, P. Valois, and M. A. von Keyserlingk. 2006. Stocking density and feed barrier design affect the feeding and social behavior of dairy cattle. J. Dairy Sci. 89:126-133.

Krawczel, P., and R. Grant. 2009. Effect of cow comfort on milk quality, productivity and behavior. Pages 15-24 in Proc. 48th Annu. Meet. Natl. Mastit. Counc., Charlotte, NC. National Mastitis Council, Verona, WI.

Krawczel, P. D., C. T. Hill, H. M. Dann, and R. J. Grant. 2008. Short communication: Effect of stocking density on indices of cow comfort. J. Dairy Sci. 91:1903-1907.

Krawczel, P. D., L. B. Klaiber, R. E. Butzler, L. M. Klaiber, H. M. Dann, C. S. Mooney, and R. J. Grant. 2012a. Short-term increases in stocking density affect the lying and social behavior, but not the productivity, of lactating Holstein dairy cows. J. Dairy Sci. 95:4298-4308.

Krawczel, P. D., C. S. Mooney, H. M. Dann, M. P. Carter, R. E. Butzler, C. S. Ballard, and R. J. Grant. 2012b. Effect of alternative models for increasing stocking density on the short-term behavior and hygiene of Holstein dairy cows. J. Dairy Sci. 95:2467-2475.

Ledgerwood, D. N., C. Winckler, and C. B. Tucker. 2010. Evaluation of data loggers, sampling intervals, and editing techniques for measuring the lying behavior of dairy cattle. J. Dairy Sci. 93:5129-5139.

Metz, J. H. M. 1985. The reaction of cows to a short-term deprivation of lying. Appl. Anim. Behav. Sci. 4:301-307.

Nelson, A. J. 1996. On-farm nutrition diagnostics. Pages 76-85 in Proc. 29th Annu. Conf. Am. Bovine Pract., San. Diego, CA. Am. Assoc. Bovine Pract., Rome, GA.

NRC. 2001. Nutrient Requirements of Dairy Cattle. 7th rev. ed. Natl. Acad. Press, Washington, DC.

Overton, M. W., D. A. Moore, and W. M. Sischo. 2003. Comparison of commonly used indices to evaluate dairy cattle lying behavior. Pages 125-130 in Proc. 5th Int. Dairy Housing Conf., Fort Worth, TX. ASAE, St. Joseph, MI.

Overton, M. W., W. M. Sischo, G. D. Temple, and D. A. Moore. 2002. Using time-lapse video photography to assess dairy cattle lying behavior in a free-stall barn. J. Dairy Sci. 85:2407-2413.

Proudfoot, K. L., D. M. Veira, D. M. Weary, and M. A. G. von Keyserlingk. 2009. Competition at the feed bunk during transition changes the feeding, standing and social behaviour of Holstein dairy cows. J. Dairy Sci. 92:3116-3123.

Rulquin, H., and J. P. Caudal. 1992. Effects of lying or standing on mammary blood flow and heart rate of dairy cows. Ann. Zootech. 41:101.

Schirmann, K., N. Chapinal, D. M. Weary, W. Heuwieser, and M. A. G. von Keyserlingk. 2012. Rumination and its relationship to feeding and lying behavior in Holstein dairy cows. J. Dairy Sci 95:3212-3217.

Schirmann, K., M. A. G. von Keyserlingk, D. M. Weary, D. M. Veira, and W. Hevwieser. 2009. Technical note: Validation of a system for monitoring rumination in dairy cows. J. Dairy Sci. 92:6052-6055.

Telezhenko, E., M. A. G. Von Keyserlingk, A. Talebi, and D. M. Weary. 2012. Effect of pen size, group size, and stocking density on activity in freestall-housed dairy cows. J. Dairy Sci. 95:3064-3069.

Tucker, C. B., D. M. Weary, and D. Fraser. 2005. Influence of neck-rail placement on free-stall preference, use, and cleanliness. J. Dairy Sci. 88:2730-2737.

Tucker, C. B., D. M. Weary, M. A. G. von Keyserlingk, and K. A. Beauchemin. 2009. Cow comfort in tie-stalls: Increased depth of shavings or straw bedding increases lying time. J. Dairy Sci. 92:2684-2690.

Tyrrell, H. F., and J. T. Reid. 1965. Prediction of the energy value of cow's milk. J. Dairy Sci. 48:1215-1223.

von Keyserlingk, M. A. G., A. Barrientos, K. Ito, E. Galo, and D. M. Weary. 2012. Benchmarking cow comfort on North America freestall dairies: Lameness, leg injuries, lying time, facility design and management for high-producing Holstein dairy cows. J. Dairy Sci. 95:7399-7408.

von Keyserlingk, M. A. G., J. Rushen, A. M. de Passillé, and D. M. Weary. 2009. Invited review: The welfare of dairy cattle - Key concepts and the role of science. J. Dairy Sci. 92:4101-4111.

Wagner-Storch, A. M., R. W. Palmer, and D. W. Kammel. 2003. Factors affecting stall use for different freestall bases. J. Dairy Sci. $86: 2253-2266$

Yang, W. Z., K. A. Beauchemin, and L. M. Rode. 2001. Barley processing, forage: concentrate, and forage length effects on chewing and digesta passage in lactating cows. J. Dairy Sci. 84:2709-2720. 